\author{
EWA WÓJTOWICZ \\ ORCID: 0000-0003-2272-1442 \\ Uniwersytet Wrocławski \\ Zakład Prawa Gospodarczego i Handlowego
}

\title{
JEDNOSTRONNIE PROFESJONALNE UMOWY \\ POŚREDNICTWA HANDLOWEGO A REGULACJA KODEKSU \\ CYWILNEGO O UMOWIE AGENCYJNEJ I UMOWIE ZLECENIA — UWAGI NA TLE WYBRANYCH UMÓW
}

\begin{abstract}
Abstrakt: Umowy o świadczenie usług pośrednictwa handlowego — podobne do umowy agencyjnej — są powszechnie zawierane w obrocie handlowym. Istnieje potencjalnie możliwość stosowania do takich umów przepisów kodeksu cywilnego o umowie zlecenia. Jednakże istnieje wiele elementów, które sprawiają, że takie umowy są zbliżone raczej do umowy agencyjnej niż do umowy zlecenia. W konsekwencji należy rozważyć stosowanie przepisów kodeksu cywilnego o umowie agencyjnej, jednak przy uwzględnieniu okoliczności, że niektóre z tych przepisów są charakterystyczne wyłącznie dla umowy agencyjnej, w tym regulacja związana z dwustronnie handlowym charakterem umowy agencyjnej oraz związana z kreowaniem przez umowę agencyjną długoterminowej relacji między stronami.
\end{abstract}

Słowa kluczowe: pośrednictwo handlowe, umowa agencyjna, umowy o świadczenie usług, przedsiębiorca

\section{UMOWY O ŚWIADCZENIE USŁUG POŚREDNICTWA HANDLOWEGO A UMOWA AGENCYJNA I UMOWY, O KTÓRYCH MOWA W ART. 750 K.C.}

Umowa agencyjna stanowi przykład — obok umowy komisu — nazwanej umowy pośrednictwa handlowego, uregulowanej w kodeksie cywilnym. Jest to umowa znana również pod rządami kodeksu handlowego i ukształtowana przez ustawodawcę jako umowa dwustronnie profesjonalna - dającym zlecenie ma być, zgodnie z art. 758 k.c., przedsiębiorca, natomiast agent ma zobowiązywać się do stałego pośredniczenia albo zawierania umów w imieniu dającego zlecenie w zakresie działalności swego przedsiębiorstwa. 
Regulacja umowy agencyjnej jest przy tym wyjątkowo rozbudowana, w znacznej części stanowiąc implementację dyrektywy o niezależnych agentach handlowych $^{1}$. Przy czym wiele przepisów ma charakter bezwzględnie obowiązujący ${ }^{2}$ albo semimperatywny ${ }^{3}$. Specyfika kodeksowej regulacji umowy agencyjnej polega w efekcie również na tym, że mimo dwustronnie profesjonalnego charakteru, wiele jej przepisów nakierowanych jest na ochronę z założenia słabszej strony stosunku zobowiązaniowego, czyli agenta ${ }^{4}$. W związku z tym w literaturze wskazuje się, że ochrona agenta jako strony słabszej stanowi istotną cechę normatywnego modelu umowy agencyjnej nie tylko w Polsce, ale także w większości państw Unii Europejskiej ${ }^{5}$.

W praktyce zawieranych jest wiele umów o świadczenie usług, które nie mogą zostać uznane za umowy agencyjne, w tym umowy wykazujące podobieństwo do umowy agencyjnej, jednak niemające wszystkich essentialia negotii tej umowy, niebędące jednocześnie innymi nazwanymi umowami pośrednictwa ani umową zlecenia. Między innymi zagadnienie to pojawia się przy jednostronnie profesjonalnych umowach pośrednictwa handlowego. O umowach o świadczenie usług nieuregulowanych innymi przepisami mówi przy tym art. 750 k.c., który do takich umów każe odpowiednio stosować przepisy o umowie zlecenia. W orzecznictwie i doktrynie uznaje się, że do umów wykazujących znaczny stopień podobieństwa do umowy agencyjnej należy w pierwszej kolejności stosować przepisy o umowie agencyjnej, a nie o umowie zlecenia. Zagadnienie potrzeby i możliwości stosowania przepisów o umowie agencyjnej do jednostronnie handlowych umów pośrednictwa stanowi przedmiot rozstrzygnięć sądów oraz zainteresowania doktryny.

W orzecznictwie i literaturze wskazuje się, że regulacja umowy zlecenia nie znajdzie zastosowania na podstawie art. 750 k.c. do takich umów nienazwanych, które są tak podobne do innych umów nazwanych, że możliwe jest stosowanie do nich per analogiam przepisów dotyczących tych innych umów, w szczególności przepisów regulujących umowę agencyjną ${ }^{6}$. Stanowisko to związane jest z założe-

${ }^{1}$ Dyrektywa Rady z dnia 18 grudnia 1986 roku w sprawie koordynacji ustawodawstw Państw Członkowskich odnoszących się do przedstawicieli handlowych działających na własny rachunek (86/653/EWG), Dziennik Urzędowy L 382, 31/12/1986 P. 0017-0021 (polskie wydanie specjalne: Rozdział 06 Tom 001 P. 177 - 181).

2 Art. $760^{2} \S 1-3$ k.c., art. $760^{1} \S 1$ k.c., art. $758^{2}$ k.c.

3 Art. $761^{3}$ k.c., art. $761^{4}$ k.c., art. $761^{5} \S 1-2$ k.c., art. $764^{3}$ k.c., art. $764^{4}$ k.c. oraz art. $761^{4}$ k.c., który określa okresy wypowiedzenia o charakterze minimalnym.

4 Por. m.in. M. Grochowski, Umowa agencyjna w orzecznictwie sąów powszechnych, „Prawo w Działaniu" 20, 2014, s. 334-335.

5 Por. E. Rott-Pietrzyk, [w:] System Prawa Prywatnego, t. 7. Prawo zobowiazań - część szczegółowa, red. J. Rajski, Warszawa 2018, s. 776; eadem, Ochrona przedsiębiorcy jako strony stabszej na przyktadzie agenta handlowego, [w:] Ochrona strony stabszej stosunku prawnego. Księga jubileuszowa ofiarowana Profesorowi Adamowi Zielińskiemu, red. M. Boratyńska, Warszawa 2016, s. 701-723.

6 Por. M.K. Osajda, Umowy nienazwane w najnowszym orzecznictwie Sąu Najwyższego, „Glosa” 2006, nr 4, s. 5; K. Kopaczyńska-Pieczniak, [w:] Kodeks cywilny. Komentarz, t. 3. Zobowiq- 
niem, że art. 750 k.c. nie wyłącza stosowania w drodze analogii do nienazwanych umów o świadczenie usług przepisów regulujących określone typy umów nazwanych i przepisy o zleceniu mogą być stosowane tylko w wypadku braku podstaw do analogicznego stosowania przepisów regulujących nazwane umowy o świadczenie usług ${ }^{7}$. W szczególności za zasadne uznaje się stosowanie przepisów regulujących umowę agencyjną do umów pośrednictwa jednorazowego ${ }^{8}$. Można się więc zastanawiać, jakie elementy przesądzają o takim stopniu podobieństwa, który mógłby uzasadniać stosowanie do danej umowy przepisów o umowie agencyjnej.

Wydaje się, że będą to różnego rodzaju umowy pośrednictwa będące umowami nienazwanymi, zawierane przez profesjonalnych pośredników, które jednak nie będą mogły zostać uznane za umowę agencyjną z uwagi na brak elementów stanowiących elementy przedmiotowo istotne. W szczególności może to mieć miejsce w razie umowy, w której wyłącznie jedna ze stron — pośrednik — będzie przedsiębiorcą lub w przypadku umowy bez elementu trwałości — gdy pośrednictwo realizowane jest jednorazowo ${ }^{9}$. Umowy takie, o ile nie będą stanowić innej poza umową agencyjną umowy nazwanej pośrednictwa, w szczególności umowy komisu, ewentualnie umowy spedycji, będą zwykle uznawane za umowę pośrednictwa zwykłego. Specyficznym przypadkiem jest umowa pośrednictwa w obrocie nieruchomościami mająca własną, choć niewyczerpującą regulację.

\section{RODZAJE UMÓW POŚREDNICTWA HANDLOWEGO W OBROCIE}

Umowa pośrednictwa zwykłego pozostaje umową nienazwaną. Pośrednictwo w literaturze rozumiane jest jako umowa, na podstawie której pośrednik zobowiązuje się dokonywać czynności faktycznych, których celem jest doprowadzenie do zawarcia określonej umowy, a jego wynagrodzenie uwarunkowane jest osiągnięciem

zania - część szczególna, red. A. Kidyba 2014, art. 750, teza nr 3; P. Nazaruk, [w:] Kodeks cywilny. Komentarz, red. J. Ciszewski, Warszawa 2014, art. 750, teza nr 15; wyrok SN z dnia 15 listopada 2004 roku, IV CK 170/04, niepubl; wyrok SN z dnia 15 listopada 2004 roku, IV CK 199/04, niepubl.; wyrok SN z dnia 28 października 1999 roku, II CKN 530/98, OSP 2000, z. 7-8, poz. 118, z glosą E. Rott-Pietrzyk; wyrok SN z dnia 15 listopada 2004 roku, IV CK 199/04, niepubl.; wyrok SN z dnia 5 grudnia 2013 roku, V CSK 33/13, OSNC - Zb. dodatkowy 2015, nr B, poz. 17.

7 Por. wyrok SN z dnia 28 października 1999 roku, II CKN 530/98, OSNC 2000, nr 5, poz. 88, s. 16, Biul. SN 1999, nr 3, s. 8, z glosą E. Rott-Pietrzyk, OSP 2000, nr 7, poz. 118, s. 393.

8 Por. m.in. E. Rott-Pietrzyk, Dopuszczalność stosowania przepisów o umowie agencyjnej do innych umów o świadczenie uslug, [w:] Prawo handlowe po przystapieniu Polski do Unii Europejskiej, red. W.J. Katner, U. Promińska, Warszawa 2010, s. 490 n.

9 Brak trwałości stosunku zobowiązaniowego uznawany jest za jeden z głównych elementów odróżniających umowę agencyjną od umowy zlecenia; por. K. Górny, [w:] Kodeks cywilny, t. 3. Komentarz. Art. 627-1088, red. M. Gutowski, Warszawa 2019, art. 758, nb 16. 
tego celu, bez względu na nakład pracy i wydatki poniesione przez pośrednika ${ }^{10}$. Ponieważ pośrednictwo polega na dokonywaniu czynności faktycznych, proponuje się stosować do tej umowy odpowiednio przepisy o zleceniu zgodnie z art. 750 k.c. ${ }^{11}$ Następujące elementy zostały jednak w orzecznictwie uznane za przemawiające za podobieństwem umowy pośrednictwa do umowy agencyjnej i, co się z tym wiąże, za stosowaniem do umowy przepisów o umowie agencyjnej, w miejsce przepisów o umowie zlecenia: dokonywanie przez pośrednika czynności faktycznych, a nie prawnych; samodzielność działania pośrednika, który nie ma obowiązku stosowania się do zaleceń zlecającego; bezpośredni cel działań pośrednika stanowi stworzenie warunków, w których zawarcie głównej umowy jest możliwe, ale już tylko z udziałem samych zainteresowanych, a nie wywołanie określonego skutku prawnego; nabywanie przez pośrednika prawa do wynagrodzenia tylko wtedy, gdy stworzone przez niego warunki doprowadzą zainteresowanych do zawarcia głównej umowy; spoczywanie całego ryzyka gospodarczego na pośredniku, który z reguły nie ma nawet prawa do zwrotu poniesionych wydatków ${ }^{12}$.

Jak podkreślano, umową agencyjną jest wyłącznie umowa, której obie strony są przedsiębiorcami, co oznacza, że za umowę agencyjną nie może zostać uznana umowa zawierana przez profesjonalnego pośrednika $\mathrm{z}$ klientem niebędącym przedsiębiorcą, $\mathrm{w}$ tym $\mathrm{z}$ konsumentem. W przypadku takiej umowy nie powstaje ale problem związany z potencjalnym stosowaniem przepisów o umowie zlecenia. Zgodnie z art. $764^{9}$ k.c. do umowy o treści określonej w art. 758 § 1 k.c., ale zawartej z ,agentem" przez osobę niebędącą przedsiębiorcą, stosuje się przepisy o umowie agencyjnej $\mathrm{z}$ wyłączeniem jednak niektórych wymienionych enumeratywnie przepisów (art. $761-761^{2}$, art. $761^{5}$ oraz art. $764^{3}-764^{8}$ k.c.). Przy czym przepis nie mówi o stosowaniu przepisów odpowiednio, co oznacza, że powinny one być stosowane wprost $^{13}$. Umowa ta jest uznawana za umowę nienazwaną ${ }^{14}$.

10 Por. P. Drapała, [w:] Kodeks cywilny. Komentarz, t. 5. Zobowiazania. Część szczegółowa, red. J. Gudowski, Warszawa 2017, art. 750, teza nr 18; M. Romanowski, Charakter prawny umowy o pośrednictwo, „Monitor Prawniczy” 1997, nr 2, s. 63 n.; T. Świerczyński, Charakter prawny umowy o pośrednictwo, „Przegląd Prawa Handlowego” 1999, nr 1, s. 23-24; L. Ogiegło, [w:] Kodeks cywilny, t. 2, red. K. Pietrzykowski, 2018, art. 750, nb 5 - por. także cytowany przez autora art. 517 kodeksu zobowiązań definiujący pośrednictwo: „Kto przyrzeka drugiemu wynagrodzenie za nastręczenie sposobności do zawarcia umowy z inną osobą albo za pośredniczenie przy zawarciu takiej umowy, obowiązany jest zapłacić wynagrodzenie tylko wtedy, gdy umowa zostanie zawarta wskutek zabiegów pośrednika".

11 Por. M. Gutowski, [w:] Kodeks cywilny, t. 3. Komentarz..., art. 750, nb 10; wyrok SA w Katowicach z dnia 23 listopada 1993 roku, I ACr 672/93, OSA 1994, Nr 11-12, poz. 63.

12 Por. wyrok SN z dnia 28 października 1999 roku, II CKN 530/98, OSP 2000/7-8/118; wyrok SN z dnia 23 listopada 2004 roku, I CK 270/04, niepubl. — dotyczące umów pośrednictwa nieruchomościami.

13 Por. K. Kopaczyńska-Pieczniak, [w:] Kodeks cywilny. Komentarz. t. 3, art. 7649 , teza nr 1; T. Wiśniewski, [w:] Kodeks cywilny. Komentarz. t. 5, art. $764^{9}$.

14 Por. K. Kopaczyńska-Pieczniak, op. cit., art. 7649, teza nr 3; A. Konert, [w:] Kodeks cywilny. Komentarz, red. M. Załucki, Warszawa 2019, art. 7649 , nb 2. 
Kolejnym przykładem umów pośrednictwa stanowiących umowy nienazwane są jedno- lub dwustronnie handlowe umowy pośrednictwa jednorazowego, ewentualnie kilkukrotnego, które z uwagi na brak wymaganego elementu stałości nie mogą zostać uznane ani za umowy agencyjne, ani za umowy, o których mowa w art. $764^{9}$ k.c. ${ }^{15}$ Pośrednictwo może być zarówno pośrednictwem stałym — gdy zobowiązanie pośrednika dotyczy bliżej nieokreślonej liczby umów, jak i pośrednictwem doraźnym, gdy usługi pośrednictwa dotyczyć mają tylko jednej umowy albo oznaczonej liczby umów. Pośrednictwo stałe związane jest często z chęcią zyskania nowych klientów na rynku i umowy przewidujące stałe świadczenie usług pośrednictwa mają najczęściej charakter dwustronnie profesjonalny ${ }^{16}$. Jednostronnie profesjonalne umowy pośrednictwa handlowego, gdy jedynie pośrednik będący przedsiębiorcą ma wiedzę i doświadczenie zawodowe w zakresie transakcji, których dotyczy pośrednictwo, są zawierane najczęściej jako umowy pośrednictwa doraźnego. Osoba, która regularnie, w sposób zorganizowany i ciągły, zawiera określonego rodzaju umowy przy pomocy pośrednika, może sama zostać uznana za przedsiębiorcę w rozumieniu art. $43^{1} \mathrm{k}$.c.

Jednymi z najczęstszych umów pośrednictwa zawieranych w obrocie są umowy pośrednictwa nieruchomościami. Zgodnie $\mathrm{z}$ art. 180 ust. 3 ustawy o gospodarce nieruchomościami ${ }^{17}$ zakres czynności pośrednictwa $\mathrm{w}$ obrocie nieruchomościami określa umowa pośrednictwa. Dla ważności umowy wymaga się zachowania formy pisemnej lub elektronicznej. Na gruncie uchylonych obecnie przepisów wskazywano, że umowa ta stanowi typ umowy nazwanej, z tym że nieuregulowanej w sposób wyczerpujący w ustawie o gospodarce nieruchomościami ${ }^{18}$. W obecnie obowiązującej wersji przepisów ustawodawca nie wprowadza wymogu profesjonalnego wykonywania czynności pośrednictwa ${ }^{19}$. Oznacza to, że umowę pośrednictwa może

15 Por. wyrok SN z dnia 28 października 1999 roku, II CKN 530/98, OSNC 2000, nr 5, poz. 88, str. 16, Biul. SN 1999, nr 3, s. 8.

16 Por. T. Świerczyński, op. cit., s. 15.

17 Ustawa z dnia 21 sierpnia 1997 roku o gospodarce nieruchomościami, tekst jedn. Dz.U. z 2018 r. poz. 2204.

18 Por. wyrok SN z dnia 23 listopada 2004 roku, I CK 270/04, niepubl.; wyrok SN z dnia 12 stycznia 2007 roku, IV CSK 267/06, OSNC-ZD 2008, Nr 1, poz. 14; wyrok SN z dnia 5 grudnia 2013 roku, V CSK 33/2013, niepubl.

19 Zgodnie z obowiązującym do dnia 31 grudnia 2013 roku uchylonym na mocy przepisów ustawy z dnia 13 czerwca 2013 roku o zmianie ustaw regulujących wykonywanie niektórych zawodów (Dz.U. z 2013 r. poz. 829) art. 180 ust. 4 ustawy o gospodarce nieruchomościami przez umowę pośrednictwa pośrednik w obrocie nieruchomościami lub podmiot prowadzący działalność w zakresie pośrednictwa w obrocie nieruchomościami zobowiązuje się do dokonywania dla zamawiającego czynności zmierzających do zawarcia umów wymienionych w ust. 1, a zamawiający zobowiązuje się do zapłaty pośrednikowi w obrocie nieruchomościami lub podmiotowi wynagrodzenia. Również uchylony ust. 1 tego artykułu wymieniał umowy mające za przedmiot prawa do nieruchomości lub ich części, w tym umowy nabycia lub zbycia praw do nieruchomości; umowy nabycia lub zbycia własnościowego spółdzielczego prawa do lokalu mieszkalnego, spółdzielczego prawa do lokalu 
zawrzeć pośrednik prowadzący działalność gospodarczą ${ }^{20}$, ale także podmiot niebędący przedsiębiorcą ${ }^{21}$. W orzecznictwie i literaturze ${ }^{22}$ wskazuje się na podobieństwo umowy o pośrednictwo nieruchomościami do umowy agencyjnej, akcentując różnice w stosunku do umowy zlecenia ${ }^{23}$. Wprawdzie obecnie ustawodawca, opisując w nadal obowiązującym art. 180 ust. 3 ustawy o gospodarce nieruchomościami treść umowy pośrednictwa, ogranicza się do stwierdzenia, że zakres czynności pośrednictwa w obrocie nieruchomościami określa umowa, jednak zdefiniowano - w ten sam sposób jak w poprzednim stanie prawnym — pojęcie pośrednictwa w obrocie nieruchomościami, określając $\mathrm{w}$ art. 179b ustawy o gospodarce nieruchomościami, że pośrednictwo w obrocie nieruchomościami polega na odpłatnym wykonywaniu czynności zmierzających do zawarcia przez inne osoby umów: nabycia lub zbycia praw do nieruchomości; nabycia lub zbycia spółdzielczego własnościowego prawa do lokalu; najmu lub dzierżawy nieruchomości lub ich części; innych umów, których przedmiotem są prawa do nieruchomości, lub ich części. Strony zawierające umowę o pośrednictwo $\mathrm{w}$ obrocie nieruchomościami nie mogą więc całkowicie dowolnie określić jej zakresu, mają jedynie swobodę co do tego, które z wymienionych przez ustawodawcę czynności pośrednika stanowić będą jej przedmiot ${ }^{24}$. Ustawodawca uchylił wprawdzie definiujący umowę pośrednictwa art. 180 ust. 4 ustawy o gospodarce nieruchomościami, co jednak nie oznacza, że umowy pośrednictwa zawierane w obrocie nieruchomościami będą mieć treść odmienną od dotychczasowej. Czynności pośrednictwa nieruchomości nadal obejmują ten sam zakres czynności. Natomiast w przypadku jednostronnie profesjonalnej umowy zawieranej przez profesjonalnego pośrednika niezbędnym elementem obowiązków korzystającego $\mathrm{z}$ usług pośrednictwa $\mathrm{w}$ obrocie nieruchomościami będzie zapłata wynagrodzenia na rzecz pośrednika. $Z$ tych względów nadal aktualne wydaje się stanowisko o podobieństwie tej umowy do umowy agencyjnej i potrzebie odpowiedniego stosowania przepisów art. $758-764^{9} \mathrm{k} . c$.

Specyficznym przypadkiem jest umowa zlecenia maklerskiego (umowa pośrednictwa giełdowego) uregulowana $\mathrm{w}$ art. 73 ustawy o obrocie instrumentami finansowymi ${ }^{25}$, która w literaturze uznawana jest za umowę nienazwaną, odrębną

użytkowego lub prawa do domu jednorodzinnego w spółdzielni mieszkaniowej; umowy najmu lub dzierżawy nieruchomości albo ich części.

${ }^{20}$ Na ogólnych zasadach, bez konieczności wcześniejszej rejestracji w rejestrze pośredników.

21 Por. J. Jaworski, [w:] Ustawa o gospodarce nieruchomościami. Komentarz, red. J. Jaworski, A. Prusaczyk, A. Tułodziecki, Warszawa 2017, art. 180, nb 7.

22 Por. D. Pęchorzewski, M. Horoszko, [w:] Gospodarka nieruchomościami. Komentarz, red. D. Pęchorzewski, Warszawa 2014, art. 180, nb 2.

${ }^{23}$ W ten sposób umowę pośrednictwa definiował uchylony art. 180 ust. 4 ustawy o gospodarce nieruchomościami.

${ }^{24}$ Por. E. Kucharczyk-Bończak, Ustawa o gospodarce nieruchomościami. Komentarz aktualizowany, LEX/el. 2019, art. 180, pkt 4.

${ }^{25}$ Ustawa z dnia 29 lipca 2005 roku o obrocie instrumentami finansowymi, tekst jedn. Dz.U. z 2018 r. poz. 2286. 
umowę nazwaną albo wariant umowy zlecenia. Jednak ustawa o obrocie instrumentami finansowymi rozstrzyga problem właściwych dla tej umowy przepisów i nakazuje odpowiednio stosować w zakresie w niej nieuregulowanym do umowy o wykonywanie zleceń nabycia lub zbycia instrumentów finansowych przepisy o umowie zlecenia, z wyłączeniem art. 737 k.c., natomiast do wykonywania zleceń nabycia lub zbycia papierów wartościowych w obrocie zorganizowanym odpowiednio przepisy o umowie komisu (art. 73 ust. 4 ustawy o obrocie instrumentami finansowymi).

Podobna regulacja znalazła się w art. $38 \mathrm{~b}$ ustawy o giełdach towarowych ${ }^{26}$ dotyczącym umowy o świadczenie usług brokerskich w zakresie obrotu towarami giełdowymi, w której towarowy dom maklerski zobowiązuje się wobec dającego zlecenie do zawierania umów nabycia lub zbycia towarów giełdowych w imieniu własnym, lecz na rachunek dającego zlecenie. W zakresie nieuregulowanym do umowy o świadczenie usług brokerskich w zakresie obrotu towarami giełdowymi art. $38 \mathrm{~b}$ ust. 5 ustawy o giełdach towarowych nakazuje stosować odpowiednio przepisy dotyczące umowy zlecenia, natomiast do zlecenia nabycia lub zbycia towarów giełdowych odpowiednio przepisy dotyczące umowy komisu. Z uwagi na treść powyższej regulacji prawnej — nakaz odpowiedniego stosowania przepisów o umowie zlecenia albo o umowie komisu — obie umowy nie mogą zostać uznane za podtyp czy też wariant umowy zlecenia ${ }^{27}$. Dla zasadności stosowania przepisów o umowie agencyjnej nie ma znaczenia sporna w doktrynie kwestia, czy umowy te stanowią umowy nazwane, czy nienazwane ${ }^{28}$ — ze względu na wyraźne wskazanie przez ustawodawcę regulacji znajdującej zastosowanie.

Potencjalnie najbardziej zbliżonymi do umowy agencyjnej są umowy pośrednictwa określane jako umowy sieciowe - umowa franchisingu oraz umowa dystrybucyjna. Są to przy tym umowy nienazwane, nieposiadające własnej regulacji w prawie polskim. Podobieństwo tych umów do siebie, a jednocześnie ich swoistość w porównaniu do pozostałych umów o świadczenie usług, skłoniło twórców Draft Common Frame of Reference (DCFR) ${ }^{29}$ do zgrupowania przepisów dotyczących tych trzech umów w jednej części DCFR, przy stworzeniu części wspólnej obejmującej przepisy dotyczące wszystkich wymienionych umów. W odrębnej części uregulowano umowy o świadczenie usług ${ }^{30}$. Obie te umowy są jednak zawierane w obrocie handlowym wyłącznie jako umowy dwustronnie

${ }^{26}$ Ustawa z dnia 26 października 2000 roku o giełdach towarowych, tekst jedn. Dz.U z 2019 r. poz. 312 .

27 Por. K. Topolewski, Przedmiot zobowiazania z umowy zlecenia, Warszawa 2015, s. 277.

28 Ibidem, s. 276 i cytowana przez autora literatura.

29 Principles, Definitions and Model Rules of European Private Law: Draft Common Frame of Reference (DCFR), red. Ch. von Bar, Munich 2008.

30 Por. E. Rott-Pietrzyk, M. Grochowski, Regulacja umów o pośrednictwo w DCFR (wzorcem dla ustawodawcy polskiego?), „Transformacje Prawa Prywatnego” 2017, nr 3, s. 52 n.; eadem, Struktura regulacji umów o pośrednictwo handlowe (wnioski prawnoporównawcze i propozycje legislacyjne), „Studia Prawa Prywatnego” 2018, nr 1, s. 3 n. 
profesjonalne i wykorzystywane są przez przedsiębiorców jako instrument trwałej współpracy prowadzącej do rozszerzenia rynków zbytu ${ }^{31}$.

\section{STOSOWANIE PRZEPISÓW O UMOWIE AGENCYJNEJ DO JEDNOSTRONNIE PROFESJONALNYCH UMÓW POŚREDNICTWA HANDLOWEGO}

Nie należy z góry odrzucać możliwości i zasadności odpowiedniego stosowania przepisów kodeksu cywilnego regulujących umowę agencyjną do jednostronnie profesjonalnych umów pośrednictwa handlowego. Pewne rozwiązania zastosowane przy umowie zlecenia nie są dostosowane do umów pośrednictwa handlowego. W regulacji umowy zlecenia nie przewiduje się wynagrodzenia jako jednego z konstrukcyjnych elementów stosunku zobowiązaniowego. Zlecenie może występować zarówno w wariancie odpłatnym, jak i bezpłatnym ${ }^{32}$. Natomiast umowy, w których swoje usługi świadczy przedsiębiorca-pośrednik, zawsze powinny być umowami odpłatnymi. Ponadto, nawet w wariancie odpłatnym, w umowie zlecenia przewidziane jest wynagrodzenie niezależne od efektów działań zleceniobiorcy, co z kolei nie jest rozwiązaniem efektywnym przy umowach pośrednictwa, dla których typowe jest wykorzystywanie prowizji powiązanej z wynikiem realizacji usługi przez pośrednika. Wynagrodzenie prowizyjne, rozumiane jako wynagrodzenie zależne od ilości bądź wartości umów zawartych dzięki agentowi, stanowi podstawowe wynagrodzenie przy umowie agencyjnej, a regulacja dotycząca wynagrodzenia jest rozbudowana. W razie braku określenia wysokości wynagrodzenia w umowie zlecenia zleceniobiorcy należeć się będzie wynagrodzenie odpowiadające wykonanej pracy, a kodeks cywilny nie zawiera bliższych wytycznych co do sposobu obliczenia wysokości wynagrodzenia. Zleceniobiorca ma, poza wynagrodzeniem, prawo do dochodzenia zwrotu wydatków, co także nie jest rozwiązaniem dostosowanym do profesjonalnego świadczenia usług — przedsiębiorca powinien co do zasady sam ponosić koszty prowadzonej przez siebie działalności. W modelu umowy zlecenia zleceniobiorca ma obowiązek stosowania się do poleceń dającego zlecenie (art. 737 k.c.), natomiast pośrednik, zwłaszcza będący przedsiębiorcą, ma zwykle większą swobodę w tym zakresie ${ }^{33}$.

Odpowiednie stosowanie przepisów o umowie agencyjnej wymaga jednak uwzględnienia specyfiki regulacji tej umowy ukształtowanej pod wpływem dyrektywy i ratio legis wielu przepisów nakierowanych na ochronę agentów uznawa-

31 Por. M. Krajewski et al., [w:] System Prawa Handlowego, t. 5. Prawo umów handlowych, red. M. Stec, Warszawa 2017, s. 516 n.

32 Por. L. Ogiegło, [w:] System Prawa Prywatnego, t. 7. Prawo zobowiazań - część szczegótowa, red. J. Rajski, Warszawa 2018, s. 626.

33 Por. T. Świerczyński, op. cit., s. 23-24. 
nych za podmioty słabsze $\mathrm{w}$ relacji $\mathrm{z}$ dającym zlecenie. $\mathrm{W}$ umowach pośrednictwa zawieranych przez profesjonalnych pośredników z podmiotami niedziałającymi w zakresie swej działalności gospodarczej lub zawodowej usługi pośrednictwa będą niejednokrotnie świadczone na rzecz podmiotów mających status konsumentów i przez to podlegających ochronie. Należy mieć również na uwadze przepisy, które są tak związane $\mathrm{z}$ dwustronnie profesjonalnym charakterem umowy agencyjnej, że ich praktyczne znaczenie dla umów, w których jedynie pośrednik jest przedsiębiorcą, będzie bardzo ograniczone. Umowa agencyjna jest zdefiniowana ponadto jako umowa kreująca zobowiązania o charakterze trwałym, zakładająca stałe świadczenie usług, dlatego też przepisy wynikające $\mathrm{z}$ takiego charakteru umowy nie będą mogły być stosowane do umów zakładających jednorazowe świadczenie usługi pośrednictwa, co, jak wskazano wcześniej, jest częstym przypadkiem przy świadczeniu usług dla nie-przedsiębiorców.

Pewną wskazówką w tym zakresie może być regulacja art. $764^{9}$ k.c. dotycząca umów o treści zbieżnej z treścią umowy agencyjnej określoną $\mathrm{w}$ art. $758 \S 1$ k.c., zawartej jednak z agentem przez osobę niebędącą przedsiębiorcą. Regulacja ta może być pomocna również dla umów pośrednictwa handlowego, które nie odpowiadają swą treścią umowie agencyjnej.

Bezprzedmiotowe byłoby stosowanie przepisów, które nakierowane są na ochronę pozycji dającego zlecenie na rynku, dotyczących umownego ograniczenia działalności konkurencyjnej (art. $764^{6}-764^{8}$ k.c.). W umowie, w której tylko jedna ze stron prowadzi działalność gospodarczą, nie można mówić o potencjalnej działalności konkurencyjnej byłego (czy też obecnego) pośrednika. Tego rodzaju postanowienia nie będą więc wprowadzane do jednostronnie profesjonalnych umów pośrednictwa handlowego, a problem stosowania tych przepisów raczej nie zaistnieje.

Podobnie, gdy kontrahentem pośrednika nie będzie przedsiębiorca, trudne byłoby spełnienie przesłanek pozytywnych, od których zależy prawo do żądania świadczenia wyrównawczego. Osoba, która nie prowadzi działalności gospodarczej, nie będzie przy pomocy pośrednika zyskiwać nowych klientów ani zwiększać obrotów z klientami dotychczasowymi. Nie będąc przedsiębiorcą, nie będzie również czerpać korzyści z umów zawieranych przez pośrednika po rozwiązaniu umowy ${ }^{34}$.

Zastanawiać się można nad zasadnością stosowania w umowach, w których jedynie pośrednik jest przedsiębiorcą, regulacji dotyczącej prawa wyłączności i prowizji należnej pośrednikowi przy zawarciu umowy z naruszeniem tego prawa. Artykuł $764^{9}$ k.c. wyłącza ten przepis, jednak zastrzeganie prawa wyłączności dla pośredników w umowach z klientami niebędącymi przedsiębiorcami jest stosowaną praktyką. Sąd Najwyższy — bez odwołania się do przepisów o umowie agencyjnej — uznał, że dopuszczalne jest dochodzenie roszczenia odszkodowawczego za

34 Por. E. Rott-Pietrzyk, Komentarz do niektórych przepisów Kodeksu cywilnego, [w:] eadem, Umowa agencyjna po nowelizacji. Art. 758-764(9) k.c. Komentarz, Kraków 2001, art. $764^{9}$ k.c., pkt 2. 
utracone korzyści w razie naruszenia prawa wyłączności w zakresie dokonywania dostaw ${ }^{35}$. W odniesieniu do umów pośrednictwa nieruchomości na wyłączność zawartych ze sprzedającymi (w tym niebędącymi przedsiębiorcami) dopuszcza się roszczenie odszkodowawcze pośrednika za utracone korzyści, gdy transakcja zostanie przeprowadzona $\mathrm{z}$ pominięciem pośrednika, natomiast przy umowach zawartych z kupującym wskazuje się na obowiązek zapłaty wynagrodzenia pośrednikowi, który został pominięty (także przy umowie zawartej bezpośrednio ze sprzedającym $)^{36}$. W orzecznictwie uzależniono uprawnienie pośrednika, któremu przysługiwało prawo wyłączności do dochodzenia wynagrodzenia prowizyjnego, od tego, czy kontrahent został skojarzony ze zbywcą nieruchomości w wyniku starań pośrednika ${ }^{37}$.

Nie jest zasadne wymaganie od podmiotu niebędącego przedsiębiorcą przedstawiania pośrednikowi-profesjonaliście informacji wymaganych $\mathrm{w}$ art. $761^{5} \mathrm{k}$.c. Przepisy te związane są z ochroną agenta. Ponadto w praktyce realizacja wszystkich obowiązków dającego zlecenie nie jest możliwa przez podmiot, który nie prowadzi księgowości związanej z działalnością gospodarczą ${ }^{38}$.

W przypadku umów pośrednictwa doraźnego nie będzie uzasadnienia dla stosowania art. $764^{1}$ k.c. wprowadzającego terminy wypowiedzenia umowy agencyjnej. Jak wskazano, jest to przepis chroniący agenta, choć nie jest wyłączony $\mathrm{w}$ art. $764^{9} \mathrm{k}$.c. Wprowadzanie stosunkowo długich terminów wypowiedzenia jest uzasadnione trwałością więzi zobowiązaniowej, za czym przemawia między innymi uzależnienie okresu wypowiedzenia od okresu wcześniejszego obowiązywania umowy agencyjnej.

W praktyce najbardziej uzasadnione wydaje się stosowanie przepisów kodeksu cywilnego o wynagrodzeniu prowizyjnym agenta, zwłaszcza że regulacja umowy zlecenia w tym zakresie jest uboższa. Przepisy te mogą być pomocne przede wszystkim do ustalania wysokości wynagrodzenia oraz momentu nabycia prawa do wynagrodzenia. Więcej wątpliwości budzi zasadność zastosowania regulacji dotyczącej wymagalności prowizji, która ma charakter ochronny dla agenta, ale jest także związana $\mathrm{z}$ długoterminowością współpracy stron $\mathrm{w}$ ramach umowy agencyjnej.

35 Por. wyrok SN z dnia 14 maja 2002 roku, V CKN 857/00, OSNC 2003, nr 7-8, poz. 108; Biul. SN 2003, nr 7; OSG 2004, nr 1, poz. 5, s. 12.

36 Por. J. Jaworski, op. cit., art. 180, nb 9.

37 Por. wyrok SA w Gdańsku z dnia 30 kwietnia 2009 roku, I ACa 249/09, POSAG 2010, nr 1, poz. 6, s. 50 .

38 Por. E. Rott-Pietrzyk, Komentarz do niektórych przepisów..., art. $764^{9}$ k.c., pkt 2. 


\title{
UNILATERALLY PROFESSIONAL COMMERCIAL MEDIATION CONTRACTS AND CIVIL CODE PROVISIONS ON AGENCY CONTRACTS AND CONTRACTS OF MANDATE - COMMENTS IN THE CONTEXT OF SELECTED CONTRACTS
}

\author{
Summary
}

Contracts on provision of mediation services similar to agency contracts are commonly concluded in commercial trade. It is potentially possible to apply Civil Code provisions on a contract of mandate to unilaterally professional mediation contracts. However, many elements make these contracts similar to agency contracts rather than contracts of mandate. In consequence the application of Civil Code provisions on agency contracts should be considered, bearing in mind that some of the provisions are specific for agency contracts only, such as provisions linked to the bilaterally professional character of agency contracts and provisions related to the fact that an agency contract creates a long-term relationship.

Keywords: commercial mediation, agency contract, contracts for the provision of services, entrepreneur

\section{BIBLIOGRAFIA}

Bar Christian von, Principles, Definitions and Model Rules of European Private Law: Draft Common Frame of Reference (DCFR), Munich 2008.

Boratyńska M., Ochrona strony słabszej stosunku prawnego. Księga jubileuszowa ofiarowana Profesorowi Adamowi Zielińskiemu, Warszawa 2016.

Ciszewski J., Kodeks cywilny. Komentarz, Warszawa 2014.

Grochowski M., Umowa agencyjna w orzecznictwie sądów powszechnych, „Prawo w Działaniu” 20, 2014, s. 327-379.

Gudowski J., Kodeks cywilny. Komentarz, t. 5. Zobowiązania. Część szczegółowa, Warszawa 2017.

Gutowski M., Kodeks cywilny, t. 3. Komentarz. Art. 627-1088, Warszawa 2019.

Jaworski J., Prusaczyk A., Tułodziecki A., Ustawa o gospodarce nieruchomościami. Komentarz, Warszawa 2017.

Katner W. J., Promińska U., Prawo handlowe po przystapieniu Polski do Unii Europejskiej, Warszawa 2010.

Kidyba A., Kodeks cywilny, Komentarz, t. 3. Zobowiązania - część szczególna, Lex 2014.

Kucharczyk-Bończak E., Ustawa o gospodarce nieruchomościami. Komentarz aktualizowany, LEX/ el. 2019.

Osajda K., Umowy nienazwane w najnowszym orzecznictwie Sądu Najwyższego, „Glosa” 2006, nr 4, s. 5-19.

Pęchorzewski D., Gospodarka nieruchomościami. Komentarz, Warszawa 2014.

Pietrzykowski K., Kodeks cywilny, t. 2. Komentarz. Art. 450-1088, Warszawa 2018.

Rajski J., Prawo zobowiazań - część szczególowa [w:] System Prawa Prywatnego, t. 7. Prawo zobowiązán - częśś szczegółowa, red. J. Rajski, Warszawa 2018.

Romanowski M., Charakter prawny umowy o pośrednictwo, „Monitor Prawniczy” 1997, nr 2.

Rott-Pietrzyk E., Komentarz do niektórych przepisów Kodeksu cywilnego, [w:] eadem, Umowa agencyjna po nowelizacji. Art. 758-764 (9) k.c. Komentarz, Kraków 2001. 
Rott-Pietrzyk E., Grochowski M., Regulacja umów o pośrednictwo w DCFR (wzorcem dla ustawodawcy polskiego?), „Transformacje Prawa Prywatnego” 2017, nr 3, s. 49-81.

Rott-Pietrzyk E., Grochowski M., Struktura regulacji umów o pośrednictwo handlowe (wnioski prawnoporównawcze i propozycje legislacyjne), „Studia Prawa Prywatnego” 2018, nr 1, s. 3-24, DOI: $10.32027 /$ SPP.18.1.5.

System Prawa Handlowego, t. 5. Prawo umów handlowych, red. M. Stec, Warszawa 2017.

Świerczyński T., Charakter prawny umowy o pośrednictwo, „Przegląd Prawa Handlowego” 1999, nr 1, s. 15-25.

Topolewski K., Przedmiot zobowiąania z umowy zlecenia, Warszawa 2015.

Załucki M., Kodeks cywilny. Komentarz, Warszawa 2019. 